\title{
CORPORATE ELITES AND CORPORATE STRATEGY: HOW DEMOGRAPHIC PREFERENCES AND STRUCTURAL POSITION SHAPE THE SCOPE OF THE FIRM

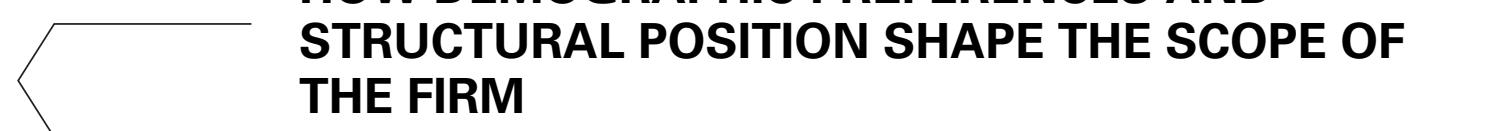

MICHAEL JENSEN ${ }^{*}$ and EDWARD J. ZAJAC ${ }^{2}$

1 University of Michigan Business School, Ann Arbor, Michigan, U.S.A.

${ }^{2}$ Kellogg School of Management, Northwestern University, Evanston, Illinois, U.S.A.

\begin{abstract}
This study combines elements of the upper echelons and agency perspectives to resolve some of the ambiguity surrounding how corporate elites affect corporate strategy. We propose and test the notion that while differences in individual characteristics of corporate elites may imply different preferences for particular corporate strategies such as diversification and acquisitions, these basic preferences, when situated in different agency contexts (e.g., CEO, outsider director, non$C E O$ top management team member), generate very different strategic outcomes. Our detailed empirical findings, based on extensive longitudinal governance and corporate strategy data from large U.S. corporations, also highlight the pitfalls of using aggregate units of analysis (e.g., board of directors or top management team) when studying the influence of corporate elites on corporate strategy. Copyright (C) 2004 John Wiley \& Sons, Ltd.
\end{abstract}

Over the last several decades strategy researchers have devoted considerable attention to the question of how corporate elites (i.e., corporate executives and directors) affect corporate strategy. Much of this research has been grounded in one of two dominant theoretical perspectives: upper echelons and agency theory (Cannella and Monroe, 1997). While both perspectives agree that corporate elites' preferences and dispositions influence corporate strategy, the upper-echelons perspective tends to emphasize the role of demography-based preferences and dispositions (Hambrick and Mason, 1984), whereas the agency theory perspective tends to emphasize the role of position-based preferences and dispositions (Fama and Jensen, 1983). Specifically, upper-echelons theorists suggest that there is a close association between corporate

Key words: corporate elites; agency theory; upper-echelons theory; diversification; acquisitions

*Correspondence to: Michael Jensen, University of Michigan Business School, 701 Tappan Street, Ann Arbor, MI 48109-1234, U.S.A. E-mail: michjen@umich.edu elites' demographic characteristics, such as age, education, and functional background experiences, and their cognitive bases and values, which in turn determines their strategy preferences and dispositions (Wiersema and Bantel, 1992). Agency theorists focus on structural analyses of corporate governance arrangements and how boards of directors align the interests of executives and shareholders (Fama, 1980; Jensen and Meckling, 1976). Indeed, agency theorists are less interested in the demographic characteristics of corporate elites, emphasizing instead the governance positions that corporate elites occupy on boards, e.g., whether they are CEOs, executive (inside) directors, or nonexecutive (outside) directors (Jensen, 1986).

While each perspective has inspired separate streams of research on how corporate elites affect corporate strategy (as reviewed by Finkelstein and Hambrick, 1996; Johnson, Daily, and Ellstrand, 1996; and Cannella and Monroe, 1997), we suggest that a joint consideration of insights from each stream can enhance our understanding of the 
relationship between corporate elites and corporate strategy. For example, while upper-echelons research on elites' demographic characteristics sheds important light on their effects on corporate strategy, it has tended to neglect the governance context in which corporate elites are situated. Research building on the agency perspective is highly sensitive to the different governance positions corporate elites occupy as executives and board members, but neglects the demographically based preferences and dispositions that corporate elites may have (independent of their position on the board).

Rather than arguing the relative merits of one perspective vs. the other, we believe there is considerable value in accepting the relevance of both demography and position. In this study, for example, we will argue that the demographically based preferences and dispositions that corporate elites bring to their governance position influence their decisions, but that these preferences and dispositions will also be affected by the role expectations associated with the corporate governance positions they occupy. By considering both demographic characteristics and governance positions, we hope to explain the basis for the mixed empirical results that have plagued research studies grounded solely in either the upper-echelons or the agency perspective (Finkelstein and Hambrick, 1996; Dalton et al., 1998). Specifically, in this study we examine how demographically based preferences and dispositions may have differential effects on corporate strategy, depending on the governance position in which these preferences and dispositions are situated.

A related issue involves the choice of unit of analysis. Agency theorists' focus on the potential conflicts of interests between CEOs, executive, and non-executive directors typically leads to discussions of how their orientations differ as a consequence of the different role they occupy in the agency relationship. Upper-echelons theorists generally de-emphasize governance differences and combine the CEO and other executives into the top management team unit of analysis (e.g., Hambrick and Mason, 1984), or even suggest combining the top management team with the nonexecutive directors into a supra-TMT (Hambrick and Finkelstein, 1996). While both approaches have contributed considerably to research on corporate elites, our study suggests that some of the empirical ambiguities associated with both perspectives may in fact be caused by their choice of unit of analysis.

Studies that have used only one or the other aggregate unit of analysis and drawn conclusions about corporate elites have implicitly assumed that corporate elites' effects on strategy and behaviors depend only on their board role or their demographic characteristics. This study seeks to show that corporate elites who are demographically similar but occupy different roles are not necessarily associated with similar strategic choices, nor are elites who are demographically different but occupy the same role.

We examine these issues by analyzing the effects of elites' demographic preferences and governance positions on corporate diversification level and acquisition activity. While most research on the scope of the firm has focused on firms' economic characteristics, such as performance and prior diversification levels (e.g., Markides, 1995), some research has focused on the importance of corporate elites and their demographic characteristics or their governance positions (e.g., Finkelstein, 1992; Lane, Cannella, and Lubatkin, 1998). By providing a comprehensive framework for analyzing the role of corporate elites in diversification and acquisitions, we hope also to contribute to a greater understanding of the important strategy content question of what predicts firms' decisions in these areas.

We test our predictions using extensive longitudinal data on diversification level and acquisition activities in a stratified random sample of 200 Fortune 500 firms from 1985 to 1995 . We find that demographic characteristics do predict corporate strategy, but that both the strength and the direction of these predictions vary significantly, depending on the governance position in which the demographic characteristics are observed.

\section{THE ROLE OF DEMOGRAPHY AND GOVERNANCE POSITION IN DIVERSIFICATION AND ACQUISITIONS}

To study the potential importance of combining a focus on demographically based and positionally based preferences and dispositions, we examine how the effects of corporate elites' functional background experiences differ depending on their governance positions. Our emphasis on 
functional background is based on the fact that it is the most widely cited demographic characteristic thought to affect corporate strategy. Many prior upper echelon studies have focused on corporate elites' functional backgrounds and their relationships with either diversification or acquisitions (see Finkelstein and Hambrick, 1996). While diversification and acquisition decisions, strictly speaking, are orthogonal decisions (since diversification could theoretically occur with no acquisition activity), these corporate strategy decisions are in fact often intertwined. Specifically, acquisitions are often viewed as an important mechanism by which a preferred diversification level is achieved (Salter and Weinhold, 1978). For example, Markides (1995: 61-66) reports that Fortune 500 firms in the 1980s adjusted their diversification level through acquisitions and divestitures rather than internal developments and divestitures. Since the theoretical arguments relating functional background experiences and diversification and acquisitions are closely related, focusing on both provides a stronger test of the general argument that it is important to consider demography and governance position jointly.

Dearborn and Simon (1958) first examined the relationship between functional background experiences and strategic decisions. They argued that corporate elites' experiences bias their attention and proposed solutions to complex business situations, and showed that executives in an experimental setting gravitated towards interpretations of a complex business situation that reflected their own functional backgrounds. Finkelstein and Hambrick (1996: 93) argue more specifically that a correspondence between functional experiences, preferences and dispositions, and strategic choices may occur through self-selection and socialization: individuals may chose functional areas that fit their cognitive models and values, but also over time become socialized and inculcated with the area's dominant mode of thinking and acting. In either case, executives with similar functional background experiences tend to converge on similar understandings of business problems and appreciate similar solutions to these problems.

While recent studies in general have only found weak empirical relationships between executives' functional background experiences and their perceptions and beliefs (Walsh, 1988; Waller, Huber, and Glick, 1995; Beyer et al., 1997; Chattopadhyay

Copyright @ 2004 John Wiley \& Sons, Ltd. et al., 1999), there is also strong empirical support that corporate elites' functional background experiences predict diversification level and acquisition activities (Song, 1982; Finkelstein, 1992; Michel and Hambrick, 1992). Hayes and Abernathy (1980) and Fligstein (1990) both argue that corporate elites' functional background experiences are reflected in their firms' diversification level and acquisition activities. They argue specifically that individuals with dominant functional experiences in finance (and accounting and law) typically perceive firms as a collection of returngenerating assets that need not be associated with a single line of business. The firm, from this perspective, can easily be viewed as a portfolio of multiple businesses, and firms led by corporate elites with dominant functional background experiences in finance are therefore more likely to emphasize growth through diversification and acquisitions.

In fact, several studies document the relationships between functional background experiences in finance and firms' diversification level and acquisition activity. Song (1982) found that finance CEOs, who are thought to typically view the firm as a bundle of financial assets, tend to prefer to diversify through acquisitions, whereas production CEOs, who are thought to emphasize more organic growth, tend to prefer diversification through internal development. Palmer and Barber (2001) report similarly that finance CEOs were more likely to complete diversifying acquisitions between 1963 and 1968 than non-finance CEOs (see also Haunschild, Henderson, and Davis-Blake, 1999). Finally, Finkelstein (1992) found that firms dominated by finance executives were likely to be more diversified and do more expensive acquisitions, and Michel and Hambrick (1992) found that firms with more executives with functional background experiences in production (as opposed to finance) diversified less (cf. Fligstein, 1987). These findings suggest a close association between the functional background of a firm's senior executives and a firm's subsequent diversification and acquisition strategies. ${ }^{1}$

\footnotetext{
${ }^{1}$ Our study is consistent with prior research on executive demography in that our hypotheses to follow refer to central tendencies, based on ceteris paribus conditions. Thus, we are not suggesting that a production or marketing CEO would never prefer an acquisition vs. internal development; rather, we are saying that when faced with the same logics for synergies (e.g., presumed economies of scale or scope), a finance CEO will on average prefer an acquisition and diversification than would a production or marketing $\mathrm{CEO}$ - for the reasons noted above.
} 
While most studies of corporate elites and corporate strategy have tended to focus either on the CEO or the executive directors, we follow Finkelstein and Hambrick's (1996) suggestion to extend the demographic arguments to include non-executive directors. This seems particularly appropriate when studying corporate-level strategies, since decisions such as acquisition and diversification will require non-executive director involvement, review, and/or approval. In discussing guidelines for board responsibilities, the Business Roundtable says that boards 'review and ... approve the financial objectives, major strategies, and plans of the corporation,' and the American Law Institute says boards 'review and approve corporate plans and actions that the board and principal senior executives consider major.'

Prior qualitative research also suggests that nonexecutive directors influence diversification and acquisitions in at least two ways: direct influence on developing and approving diversification and acquisition strategy and indirect influence through their function as 'sounding boards for management' (Lorsch and MacIver, 1989; Demb and Neubauer, 1992; McNulty and Pettigrew, 1996). Finally, including non-executive directors in our theoretical discussion and empirical analyses enables us to present more fine-grained and comprehensive analyses of the importance of the elites' demographic characteristics on corporate strategy (e.g., by examining differences across alternative definitions of corporate elites).

The prior discussion suggests the following two core hypotheses:

Hypothesis 1: Firms with more finance corporate elites are more likely to engage in high levels of diversification.

Hypothesis 2:Firms with more finance corporate elites are more likely to engage in greater acquisition activity.

Note that the previous arguments focus exclusively on the association between corporate elites' functional background experiences and corporate strategy, and implicitly treat corporate elites as a homogeneous group distinguished only by the presence/absence of certain functional background experiences. However, a consideration of agency theory would suggest that the homogeneity assumption may be problematic and that corporate elites' strategy preferences and dispositions are determined not only by their functional background experiences, but also by their governance role (Fama and Jensen, 1983). Agency theorists argue specifically that shareholders and executives may have different interests and that the function of governance arrangements such as the board of directors is to align their interests (e.g., Fama and Jensen, 1983). While all directors are assumed to act in the interest of the shareholders, non-executive directors are especially important because of their presumed independence vis-à-vis corporate executives (Fama, 1980). Indeed, one of the most commonly prescribed remedies to increase corporate boards' governance effectiveness is to increase the number of non-executive directors relative to executive directors (Walsh and Seward, 1990).

Distinguishing between executive and non-executive directors is particularly important when focusing on decisions where top managers and shareholders' interests may differ, such as diversification and acquisition activities. From this perspective, the most important determinant of corporate elites' interests in diversification and acquisitions is rooted in whether they hold the position of executive director vs. non-executive director. Agency theorists argue that the specialization of management and risk-bearing functions between executives and shareholders creates different interests between executive vs. non-executive directors (Fama, 1980). Shareholders can use the stock markets to diversify their investment portfolios and hedge against the risk of any particular corporation's failure. However, executives often have much of their wealth, particularly their human capital, tied to the corporation for whom they work (Beatty and Zajac, 1994). Amihud and Lev (1981) and Tosi and Gomez-Mejia (1989) argue that executives therefore prefer a higher level of firm diversification than would shareholders, since it provides them with a form of personally valued diversification. In addition, greater diversification, as a mechanism for growing the size of the corporation, is often associated with higher executive compensation, social prominence, and public prestige (Jensen, 1986; Gomez-Mejia and Wiseman, 1997). Moreover, to the extent that acquisitions are 'a standard approach to diversification' (Salter and Weinhold, 1978: 166), 
it also follows that executive directors may have a stronger preference for acquisitions than nonexecutive directors. In fact, Jensen (1986) notes that acquisitions often are the result of executives using firms' 'free cash flows' on wasteful attempts to grow the firm beyond a level that is value maximizing for shareholders. ${ }^{2}$

Non-executive directors, however, when compared with executives, do not face the same employment risk nor do they receive the same perks of public attention and prestige. They are therefore more likely to act in accordance with the director-role expectations and protect the interests of the shareholders they represent. These arguments suggest that finance executive directors, who face the problem of under-diversified wealth, are likely to prefer greater corporate diversification and more acquisitions than finance non-executive directors. Indeed, non-executive directors are often seen as helping to counteract executives' preferences for (and maintenance of) greater diversification (Goodstein and Boeker, 1991; Westphal, 1998). This discussion above suggests the following hypotheses:

Hypothesis 3: Having more finance executive directors (as opposed to more finance nonexecutive directors) will be associated with high levels of diversification.

Hypothesis 4: Having more finance executive directors (as opposed to more finance nonexecutive directors) will be associated with greater acquisition activity.

The agency theory argument regarding the importance of positional differences can also be extended to focus on the CEO, who occupies a unique position in corporate governance. In large U.S. corporations, the CEO is typically the most visible individual, and most closely associated with the overall performance of the firm. This suggests that, among the group of executive directors, a CEO may have preferences that differ from those of other directors. Indeed, Fama and Jensen

\footnotetext{
${ }^{2}$ While Jensen (1986) also suggests that free cash flow can be squandered through unnecessary overinvestment in R\&D and other capital investments, the opportunities for growing the firm (for the benefit of its management) are greatest when diversifying (Hypothesis 3), which is more often accomplished via acquisition (Hypothesis 4). We thank an anonymous reviewer for raising this issue.
}

(1983) explicitly emphasize the importance of distinguishing between CEOs and the other executive directors. They argue that even though CEOs often dominate corporate decision processes, the other executive directors serve an important function as the non-executive directors' primary source of information about both firm and CEO performance. The non-CEO executive directors are in the precarious position of being beholden to the CEO because of their lower position in the corporate hierarchy, but also having to act as directors and monitor and control the CEO on behalf of the shareholders.

These arguments suggest that the non-CEO executive directors' interests cannot a priori be assumed to align only with the CEOs interests. Several researchers have argued that executives rarely constitute cohesive teams. For example, Ocasio (1994) views CEO succession in the first decade of a CEO's tenure as an instance of circulation of power emphasizing shifting political coalitions and incessant political struggles. He argues that conflict among corporate elites is an important force for change, and finds that having more executive directors increases CEO succession under economic adversity. Hambrick (1994) notes similarly that most top management teams would be better described as top management groups, given their low levels of behavioral integration (defined as the degree to which top managers engage in mutual and collective interaction). The potential lack of cohesion among executives has led some scholars to note that 'strategic leadership occurs within a complex social system of multiple leaders with multiple agendas - both private and public - that reflect multiple realities and the needs of multiple constituencies' (Jackson, 1992: 346).

It may be particularly useful to distinguish between CEOs and non-CEO corporate elites when studying the association between functional background experiences in finance and diversification and acquisition strategies because the CEO is likely to have a particularly strong interest in both. Specifically, individuals occupying the CEO role are likely to gain the most from diversification, as they benefit most directly from the social perquisites that accompany growing the scale and scope of their corporations, and they are also likely to have the lowest level of personal (human and financial) wealth diversification. Moreover, since CEOs are the most visible top managers, they may be particularly interested in growing the firm 
through acquisitions: "who can doubt the appeal of the titles awarded by the financial community; being called a "gunslinger," "white knight," or "raider" can quicken anyone's blood' (Hayes and Abernathy, 1980: 76). Hayward and Hambrick (1997) suggest that the visibility of CEOs and the accompanying public attention influence their acquisition behavior, and they show that CEO media praise actually increases the premiums their firms are willing to pay for acquisitions, which suggests that CEOs are influenced by the public attention they receive. We expect therefore that, ceteris paribus, finance CEOs are likely to favor personally prestigious and risk-reducing corporate strategies such as diversification and acquisition to a greater extent than would finance non-CEO corporate elites (i.e., all other executive and nonexecutive directors): ${ }^{3}$

Hypothesis 5: Having a finance CEO (as opposed to finance non-CEO corporate elites) will be associated with high levels of diversification.

Hypothesis 6: Having a finance CEO (as opposed to finance non-CEO corporate elites) will be associated with greater levels of acquisition activity.

\section{METHOD}

\section{Sample}

To test the hypotheses, we generated a stratified, random sample of 200 industrial corporations from the 1985 Fortune 500, i.e., 40 corporations from the Fortune 100, 40 from the Fortune 101-200, etc. While the benefits of random sampling are well understood by researchers, we believe that the merits of random sampling have not been fully recognized and exploited in prior empirical work on diversification and acquisitions (e.g., Hoskisson, Johnson, and Moesel, 1994; Haunschild et al., 1999). Specifically, the confidence with which one can draw conclusions from empirical studies of strategic phenomena is significantly limited if the

\footnotetext{
${ }^{3}$ While CEOs' stronger preferences for diversification may lead firms to pursue diversification even when it is not in the interests of their shareholders, we are not suggesting that shareholder value destruction always results. Rather, we simply suggest that the differences in preferences for diversification make it more likely that CEOs would choose diversification over other strategic options than would other non-CEO corporate elites.
}

sample is constructed of firms that have (as a requirement for inclusion in the sample) experienced the phenomenon under study. Our sample is therefore constructed independently of the dependent variables included in the study to avoid problems associated with sample selection bias. The random sample also includes firms that were later acquired by other firms, thereby avoiding survivor bias. The timeframe of the study is 1985 to 1995 .

Data on acquisition activity were taken from the Securities Data Corporation's database (SDC includes all acquisitions over $\$ 5 \mathrm{M}$ ) and diversification and financial data came from Compustat. Data on corporate elite demography and board structure and composition were obtained from The Dun and Bradstreet Reference Book of Corporate Management, Standard and Poor's Register of Corporations, Directors, and Executives, Who's Who in America, Who's Who in Finance and Industry, and corporate proxy statements. Consistent with prior upper-echelons research, the study focuses only on corporate elites, i.e., individuals who are executives in the focal firm or other industrial firms. Observations (corporation-year) were eliminated if data were missing for more than a quarter of executives and non-executive directors or if CEO data were missing (cf. Westphal and Zajac, 1997). The final sample consists of 1329 observations.

\section{Dependent and independent variables}

Following previous diversification and corporate elites research (e.g., Wiersema and Bantel, 1992; Hoskisson et al., 1993; Westphal, 1998), we measure diversification using the entropy measure of diversification (Palepu, 1985):

$$
\sum_{i=1}^{n} P_{i} \ln \left(1 / P_{i}\right)
$$

where $P$ is the share of segment $i$ 's sales of the firm's total sales (dollar values) and $\left(1 / P_{i}\right)$ is used as a weight to account for the importance of the segment for total sales. This measure is useful because it takes into consideration both the number of segments each firm operates in as well as the importance of each segment. However, the differences in revealed preference for diversification may be particularly pronounced in the case of unrelated diversification as opposed to 
related diversification. ${ }^{4}$ We therefore test the diversification hypotheses on both related and unrelated diversification, and defined highly diversified firms as firms whose degree of related and unrelated diversification were one standard deviation above the mean level of diversification. Markides (1995) notes that it is practically impossible to know a priori exactly when firms are over-diversified because each firm has a different optimal limit depending on their internal resources and competitive environment. He therefore used a similar approach to define 'over-diversified firms' as firms whose diversification levels were one-half of a standard deviation above the overall mean (our definition is thus more conservative)..$^{5}$ Acquisition activity is measured in total dollar amounts per year (sum of all acquisitions per year).

We begin by testing our predictions using the most aggregate corporate elite unit of analysis: the full board of directors. We then disaggregate this group of corporate elites into two subgroups: executive and non-executive directors. By distinguishing between executive and non-executive directors with similar demographic characteristics, we explicitly take into consideration how these groups' different functions in corporate governance influence their strategy preferences and dispositions. Finally, given the CEO's unique governance position, we take the distinction between executive and non-executive directors one step further and distinguish between the CEO and the other corporate (executive and non-executive) directors.

This process of disaggregation leads us to use four models for each dependent variable, with the main independent variables differing across each model. The first model in each set is a baseline model that only contains control variables. The second model focuses on the number of finance corporate elites, defined here by the number of both executive and non-executive directors with functional background experiences in finance (note that all models control for the total number of corporate elites, obviating the need for a proportional measure). Based on individuals' entire pre-CEO career histories, we define finance background as

\footnotetext{
${ }^{4}$ Related diversification arises from operating in several 4-digit (SIC) segments within a 2-digit segment, whereas unrelated diversification arises from operations in several 2-digit segments (Hoskisson et al., 1993).

${ }^{5}$ To test the sensitivity of our results to different definitions of 'highly diversified,' we also used Markides' (1995) definition as well as continuous measures and obtained similar results.

Copyright $\odot 2004$ John Wiley \& Sons, Ltd.
}

dominant (at least 5 years more in finance than in other functions) functional experience in finance (or accounting and law) (note that we do not include executives' CEO tenure when determining their dominant functional background experience). The third model splits the number of corporate elites with finance backgrounds into finance executive and non-executive subsets. Note that most upper-echelons research equates the executive directors with the top management team (e.g., Finkelstein and Hambrick, 1990; Finkelstein, 1992; Haleblian and Finkelstein, 1993). The fourth model distinguishes between finance CEOs (dummy variable: 1 if finance, 0 otherwise) and the other finance non-CEO directors (including executive and non-executive directors).

Models 3 and 4 thus represent different disaggregations of the corporate elite unit of analysis, which allows distinguishing the effects of demography across agency positions: the executive vs. non-executive directors and the CEO vs. the other executive and non-executive directors. In sum, the four models, when taken together, allow comparison of the effects of corporate elites' demographic preferences on corporate strategy across different governance positions. All demographic variables are lagged 1 year.

\section{Control variables}

Power is an important factor in studies of strategic decision making. Finkelstein (1992) shows that power-weighted top management teams are stronger predictors of diversification and acquisitions than teams that are not power-weighted. Zajac and Westphal (1996) show similarly that CEO's preferences for successors are realized more often when accompanied with greater power. Since the CEO typically is the single most powerful member of the corporate elite and often considered the most important determinant of other corporate elites' influence (Lorsch and MacIver, 1989; Hambrick, 1994), we control for CEO power. By controlling for CEO power, we attempt to eliminate the alternative explanation that differences in effects across governance positions are explainable solely in terms of differences in power; i.e., when CEOs are very powerful, non-CEO corporate elites may have little influence on corporate strategy.

Following previous research, we use two different indicators of CEO power: CEO duality (where 
the same individual is both CEO and chairperson of the board) and CEO relative board tenure (defined as the CEO's board tenure divided by the average tenure of the other board members). It is easier for both executive and non-executive directors to exert influence when different individuals occupy the CEO and chairperson roles because such a governance structure provides directors with the opportunity to organize around multiple individuals with formal power. Similarly, to the extent CEOs have relatively long board tenure, they have been instrumental in recruiting the other directors, which makes it more difficult for them to disagree with the CEOs. These two indicators are among the most used indicators of power in corporate elite research (e.g., Mallette and Fowler, 1992; D’Aveni and Kesner, 1993; Zajac and Westphal, 1996). In the analyses reported here, we entered the power indicators as main effects; however, in separate analyses, we also controlled for all the different power-demography interaction effects. Neither of the power-demography interactions was significant, nor did they change the results reported here, which suggests that the differences across governance positions reported here are not simply explainable in terms of power differences.

We also control for firm size, which has been shown to be associated with diversification levels and restructuring activity (Montgomery, 1982; Hoskisson et al., 1994). Firm size is defined and measured as the natural logarithm of total firm assets. While firm size is an indirect measure of the resources available to the firm to pursue diversification and acquisition strategies, Jensen (1986) argues that a more precise measure is the amount of free cash flow available. Chatterjee and Wernerfelt (1991) operationalize this concept, and suggest that the availability of internal funds or unused debt capacity favors higher levels of diversification. They define internal funds in terms of the debt to market value ratio (natural logarithm of the ratio of long-term debt to market value) and the debt capacity in terms of the current ratio (ratio of current assets to current liabilities). We also control for firm performance, which has been shown to be associated with diversification and acquisition activities (e.g., Markides, 1995; Wiersema and Bantel, 1992). It is defined and measured as ROA (return on assets).

Prior diversification level has also been shown to be associated with acquisition activity (Markides, 1995; Hoskisson et al., 1994). This variable is measured at time $t$ using the entropy measure described above, and we control for both linear and curvilinear (using squared terms) effects (Markides, 1995). Specifically, we control for total diversification, which is defined as the sum of related and unrelated diversification (Palepu, 1985). Finally, the analyses also control for the year of observation. Hoskisson and Hitt (1994) and Markides (1995) argue that firms have reduced their level of diversification throughout the period studied here. This suggests controlling for the year of observation as firms are expected to be less diversified over time. We use year dummies in all the analyses (separate analyses using a single control for year produced similar results). The financial control variables are lagged 1 year. Table 1 provides summary statistics and bivariate correlations for all data pooled.

\section{Analysis}

We used random effects logistic regression to analyze whether demography and governance position affect the likelihood of being highly diversified. The final data structure is a pooled time series, where firm-year represents the observation, and the dependent variable is a dichotomous variable coded one if the firm is highly diversified and zero otherwise. Unobserved heterogeneity, which may occur because each firm contributes multiple observations that are not independent from each other, is always a potential problem in pooled time series (Petersen and Koput, 1991). A common approach to addressing problems of unobserved heterogeneity is to insert additional firm-specific error terms that are either fixed over time for each firm (fixed-effects models), or vary randomly over time for each firm (random-effects models) (Sayrs, 1989). We used random-effects models for the following reasons. First, fixed-effects models typically produce biased estimates of the fixed effects when the time period is relatively short (Chintagunta, Jain, and Vilcassim, 1991; Heckman, 1981). While the time frame of this study is 10 years, some firms contribute fewer than 10 observations because they were merged with other firms or because of missing data. Second, since most of the firms are either highly diversified or not throughout the whole period, the models cannot be estimated using the fixed-effect approach because this approach requires variance in both dependent and independent variables to assure that 


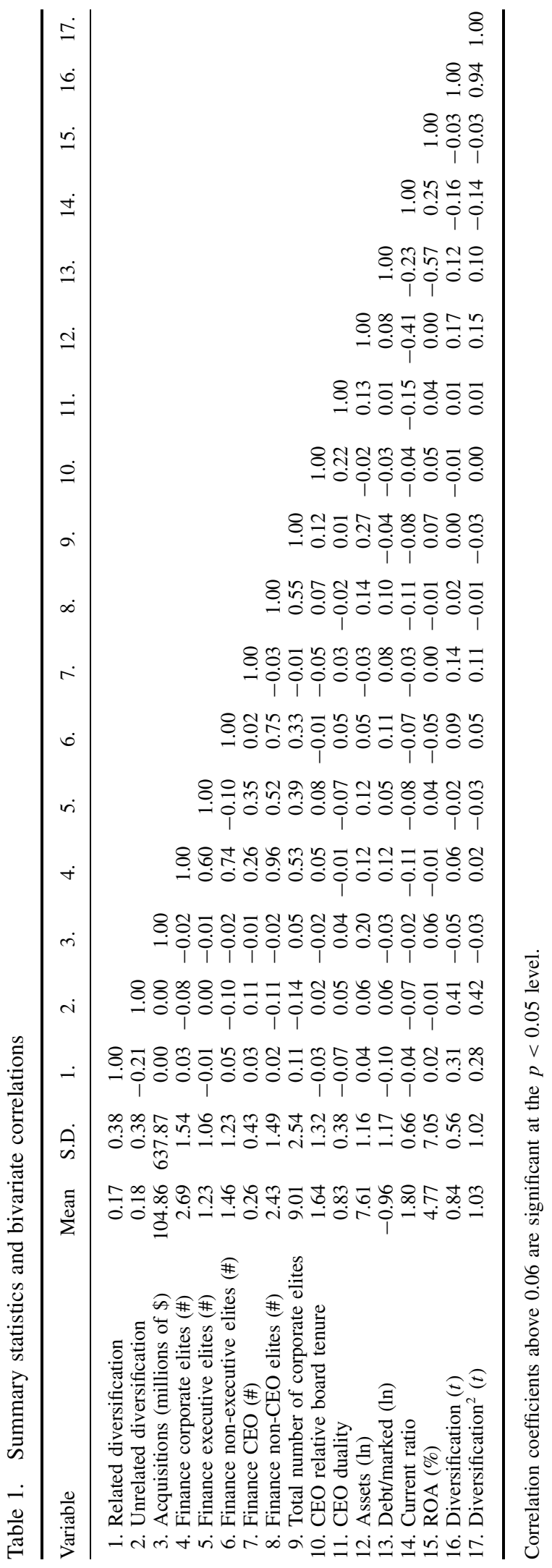


these variables are distinguishable from the fixed effects (Judge et al., 1985).

Similarly, we used random-effects tobit regression to analyze acquisition activities. Tobit regression is appropriate when the sample contains limited or censored dependent variables (Tobin, 1958). The concentration of observations at the limiting value often observed in data with limited dependent variables violates the linearity assumption of least squares. Most firms in this sample do not acquire businesses in any given year and the consequence is that the observed values of acquisitions concentrate on the value zero. Tobit models correct for such concentration of observations at the limiting value, making it possible to estimate the relationship between acquisitions and other variables. The random-effects tobit model has the following form:

$$
y_{i t}^{*}=\mathbf{X}_{i t} \beta+\varepsilon_{i t}+v_{i}
$$

where $y^{*}$ is an unobserved latent variable representing the propensity or capacity of the firm to acquire businesses that is only realized as actual acquisitions, $y$, if that capacity exceeds zero, and $v_{i}$ is a normally distributed random effect. This means that even though many observations have an identical score of zero on acquisitions, they can still be considered as having different scores on the latent variable (Breen, 1996). The relationship between the observed and latent variables is specified this way:

$$
\begin{aligned}
& y_{i t}=y_{i t}^{*} \quad \text { if } \quad y^{*}>c \quad \text { and } \\
& y_{i t}=c \quad \text { if } \quad y^{*}<c
\end{aligned}
$$

where $c$ is the threshold for censoring (zero in this case). ${ }^{6}$ A Durbin-Watson test showed that autocorrelation is not a problem (Durbin-Watson statistic $=1.99$ ). To test the stability of the results, we recoded the dependent variable into dichotomous variables and used a random effects logistic regression procedure to test the hypotheses. Again, the results are fundamentally the same as those obtained using the tobit procedure. We finally used

\footnotetext{
${ }^{6}$ A likelihood-ratio test comparing the random-effects model with the pooled tobit model was insignificant, suggesting that the panel-level variance component is unimportant and separate analyses confirmed that the results did not differ across these models.
}

maximum-likelihood Wald tests to test the significance of differences between regression coefficients (Greene, 1997).

\section{RESULTS}

\section{Diversification}

Table 2 reports the results of random-effects logistic regression analyses of the predictors of high diversification. Models 2 and 6 suggest that firms with more finance corporate elites are more likely to be highly diversified, as suggested in Hypothesis 1. However, comparing the two models also suggests that the effect of finance corporate elites is stronger in the case of unrelated diversification than related diversification. The disaggregation of the corporate elites into executive and nonexecutive directors is shown in Models 3 and 7. They show that neither the finance executive director nor the finance non-executive director units of analysis predict the likelihood of high related or high unrelated diversification. Moreover, the difference between the finance executive director and finance non-executive director effects is not statistically significant in either of the cases. These results indicate that Hypothesis 3, which had argued that finance executive directors are associated with more diversification than finance non-executive directors, cannot be supported.

This non-finding might appear surprising, given the prevalent use of the insider (executive) vs. outsider (non-executive) director variable in top management team research (e.g., Finkelstein and Hambrick, 1990; Haleblian and Finkelstein, 1993). However, we investigated this issue further in empirical analyses not reported here, and found that the main reason for these non-significant findings was that the finance non-CEO executives were more like the finance non-executives than the finance CEOs, which interestingly provides further support for the logic of our further disaggregation between CEOs and non-CEO elites, the results of which are shown in Models 4 and 8 below.

Models 4 and 8, which distinguish between finance CEOs and finance non-CEO directors, show that firms with finance CEOs are significantly more likely to be highly diversified than are firms with non-finance CEOs. Having a finance CEO (as opposed to finance non-CEO directors) 
Table 2. Random effects logistic regression: high diversification ${ }^{\mathrm{a}}$

\begin{tabular}{|c|c|c|c|c|c|c|c|c|}
\hline & \multicolumn{4}{|c|}{ Related diversification } & \multicolumn{4}{|c|}{ Unrelated diversification } \\
\hline & (1) & (2) & (3) & (4) & $(5)$ & (6) & (7) & (8) \\
\hline $\begin{array}{l}\text { Finance corporate } \\
\text { elites }(\#)\end{array}$ & & $\begin{array}{r}0.23 \dagger \\
(0.17)\end{array}$ & & & & $\begin{array}{l}0.41^{* *} \\
(0.15)\end{array}$ & & \\
\hline $\begin{array}{l}\text { Finance executive } \\
\text { elites (\#) }\end{array}$ & & & $\begin{array}{c}-0.27 \\
(0.30)\end{array}$ & & & & $\begin{array}{c}0.01 \\
(0.22)\end{array}$ & \\
\hline $\begin{array}{l}\text { Finance non- } \\
\quad \text { executive elites (\#) }\end{array}$ & & & $\begin{array}{c}0.00 \\
(0.23)\end{array}$ & & & & $\begin{array}{c}-0.04 \\
(0.19)\end{array}$ & \\
\hline Finance CEO (\#) & & & & $\begin{array}{l}1.84^{* * *} \\
(0.50)\end{array}$ & & & & $\begin{array}{l}1.31^{* *} \\
(0.45)\end{array}$ \\
\hline $\begin{array}{l}\text { Finance non-CEO } \\
\text { elites (\#) }\end{array}$ & & & & $\begin{array}{c}0.18 \\
(0.15)\end{array}$ & & & & $\begin{array}{l}-0.68^{* * *} \\
(0.18)\end{array}$ \\
\hline $\begin{array}{l}\text { Total number of } \\
\text { corporate elites }\end{array}$ & $\begin{array}{c}0.03 \\
(0.08)\end{array}$ & $\begin{array}{c}0.05 \\
(0.13)\end{array}$ & $\begin{array}{c}0.07 \\
(0.15)\end{array}$ & $\begin{array}{c}-0.01 \\
(0.11)\end{array}$ & $\begin{array}{c}-0.15 \dagger \\
(0.08)\end{array}$ & $\begin{array}{c}-0.51^{* * *} \\
(0.14)\end{array}$ & $\begin{array}{c}-0.23 \dagger \\
(0.12)\end{array}$ & $\begin{array}{c}-0.00 \\
(0.11)\end{array}$ \\
\hline $\begin{array}{l}\text { CEO relative } \\
\text { board tenure }\end{array}$ & $\begin{array}{r}-0.26 \dagger \\
(0.15)\end{array}$ & $\begin{array}{r}-0.31^{*} \\
(0.13)\end{array}$ & $\begin{array}{c}-0.20 \\
(0.13)\end{array}$ & $\begin{array}{r}-0.10 \\
(0.13)\end{array}$ & $\begin{array}{c}0.04 \\
(0.15)\end{array}$ & $\begin{array}{c}0.16 \\
(0.16)\end{array}$ & $\begin{array}{c}0.23 \\
(0.14)\end{array}$ & $\begin{array}{r}-0.03 \\
(0.15)\end{array}$ \\
\hline CEO duality & $\begin{array}{r}-1.07^{*} \\
(0.50)\end{array}$ & $\begin{array}{r}-1.16^{*} \\
(0.51)\end{array}$ & $\begin{array}{r}-1.06^{*} \\
(0.49)\end{array}$ & $\begin{array}{r}-1.29^{*} \\
(0.54)\end{array}$ & $\begin{array}{c}0.27 \\
(0.52)\end{array}$ & $\begin{array}{c}-0.61 \\
(0.57)\end{array}$ & $\begin{array}{c}-0.36 \\
(0.55)\end{array}$ & $\begin{array}{c}-0.50 \\
(0.57)\end{array}$ \\
\hline Assets $(\ln )$ & $\begin{array}{r}-0.08 \\
(0.15)\end{array}$ & $\begin{array}{r}-0.00 \\
(0.18)\end{array}$ & $\begin{array}{c}-0.21 \\
(0.23)\end{array}$ & $\begin{array}{r}0.39^{*} \\
(0.19)\end{array}$ & $\begin{array}{c}0.42 \dagger \\
(0.24)\end{array}$ & $\begin{array}{l}0.88^{* *} \\
(0.29)\end{array}$ & $\begin{array}{c}-0.38 \\
(0.30)\end{array}$ & $\begin{array}{l}0.94^{* *} \\
(0.29)\end{array}$ \\
\hline Debt/market (ln) & $\begin{array}{r}-0.46 \dagger \\
(0.24)\end{array}$ & $\begin{array}{l}-1.14^{* * *} \\
(0.27)\end{array}$ & $\begin{array}{c}-0.31 \\
(0.28)\end{array}$ & $\begin{array}{l}-1.06^{* * *} \\
(0.29)\end{array}$ & $\begin{array}{c}-0.09 \\
(0.21)\end{array}$ & $\begin{array}{l}0.82^{\text {*** }} \\
(0.22)\end{array}$ & $\begin{array}{l}1.09^{* * *} \\
(0.21)\end{array}$ & $\begin{array}{l}0.52^{* *} \\
(0.20)\end{array}$ \\
\hline Current ratio & $\begin{array}{c}-0.11 \\
(0.42)\end{array}$ & $\begin{array}{r}-0.83^{*} \\
(0.38)\end{array}$ & $\begin{array}{c}-0.36 \\
(0.44)\end{array}$ & $\begin{array}{r}-0.86^{*} \\
(0.41)\end{array}$ & $\begin{array}{c}0.01 \\
(0.42)\end{array}$ & $\begin{array}{c}0.24 \\
(0.40)\end{array}$ & $\begin{array}{l}0.07 \\
(0.41)\end{array}$ & $\begin{array}{r}0.98^{*} \\
(0.42)\end{array}$ \\
\hline $\begin{array}{l}\text { Return on assets } \\
\text { (ROA) }\end{array}$ & $\begin{array}{r}-0.08^{*} \\
(0.03)\end{array}$ & $\begin{array}{c}-0.05 \\
(0.03)\end{array}$ & $\begin{array}{r}-0.07^{*} \\
(0.03)\end{array}$ & $\begin{array}{c}-0.05 \\
(0.03)\end{array}$ & $\begin{array}{c}0.05 \\
(0.04)\end{array}$ & $\begin{array}{r}0.09^{*} \\
(0.04)\end{array}$ & $\begin{array}{c}0.05 \\
(0.03)\end{array}$ & $\begin{array}{c}0.06 \\
(0.04)\end{array}$ \\
\hline Year 1986 & $\begin{array}{c}0.24 \\
(0.67)\end{array}$ & $\begin{array}{c}0.17 \\
(0.67)\end{array}$ & $\begin{array}{c}0.25 \\
(0.68)\end{array}$ & $\begin{array}{c}-0.23 \\
(0.67)\end{array}$ & $\begin{array}{c}-1.15 \dagger \\
(0.69)\end{array}$ & $\begin{array}{r}-0.93 \dagger \\
(0.68)\end{array}$ & $\begin{array}{c}-0.90 \\
(0.64)\end{array}$ & $\begin{array}{c}-1.09 \\
(0.75)\end{array}$ \\
\hline Year 1987 & $\begin{array}{r}-0.58^{*} \\
(0.67)\end{array}$ & $\begin{array}{c}-0.63 \\
(0.68)\end{array}$ & $\begin{array}{c}-0.63 \\
(0.68)\end{array}$ & $\begin{array}{c}-0.69 \\
(0.68)\end{array}$ & $\begin{array}{c}-2.15^{* *} \\
(0.72)\end{array}$ & $\begin{array}{c}-2.09^{* *} \\
(0.72)\end{array}$ & $\begin{array}{r}-1.56^{*} \\
(0.65)\end{array}$ & $\begin{array}{c}-2.28^{* *} \\
(0.78)\end{array}$ \\
\hline Year 1988 & $\begin{array}{r}-0.33 \\
(0.69)\end{array}$ & $\begin{array}{r}-0.43 \\
(0.69)\end{array}$ & $\begin{array}{r}-0.34 \\
(0.69)\end{array}$ & $\begin{array}{c}-0.60 \\
(0.70)\end{array}$ & $\begin{array}{c}-2.34^{* *} \\
(0.74)\end{array}$ & $\begin{array}{c}-2.43^{* *} \\
(0.73)\end{array}$ & $\begin{array}{c}-2.01^{* *} \\
(0.70)\end{array}$ & $\begin{array}{c}-2.83^{* * *} \\
(0.81)\end{array}$ \\
\hline Year 1989 & $\begin{array}{c}0.34 \\
(0.69)\end{array}$ & $\begin{array}{c}0.16 \\
(0.70)\end{array}$ & $\begin{array}{c}0.41 \\
(0.70)\end{array}$ & $\begin{array}{c}0.04 \\
(0.72)\end{array}$ & $\begin{array}{c}-3.28^{* * *} \\
(0.80)\end{array}$ & $\begin{array}{c}-3.35^{\text {*** }} \\
(0.83)\end{array}$ & $\begin{array}{c}-2.72^{* * *} \\
(0.77)\end{array}$ & $\begin{array}{c}-3.48^{* * *} \\
(0.86)\end{array}$ \\
\hline Year 1990 & $\begin{array}{c}0.04 \\
(0.68)\end{array}$ & $\begin{array}{c}-0.12 \\
(0.70)\end{array}$ & $\begin{array}{c}0.06 \\
(0.70)\end{array}$ & $\begin{array}{c}-0.35 \\
(0.72)\end{array}$ & $\begin{array}{c}-2.77^{* *} \\
(0.80)\end{array}$ & $\begin{array}{c}-2.55^{* *} \\
(0.77)\end{array}$ & $\begin{array}{c}-2.07^{* *} \\
(0.76)\end{array}$ & $\begin{array}{c}-2.76^{* *} \\
(0.86)\end{array}$ \\
\hline Year 1991 & $\begin{array}{c}-0.27 \\
(0.69)\end{array}$ & $\begin{array}{c}-0.44 \\
(0.71)\end{array}$ & $\begin{array}{c}-0.26 \\
(0.71)\end{array}$ & $\begin{array}{c}-0.88 \\
(0.76)\end{array}$ & $\begin{array}{r}-1.83^{*} \\
(0.79)\end{array}$ & $\begin{array}{c}-2.09^{* *} \\
(0.77)\end{array}$ & $\begin{array}{r}-1.42^{*} \\
(0.72)\end{array}$ & $\begin{array}{r}-2.03^{*} \\
(0.84)\end{array}$ \\
\hline Year 1992 & $\begin{array}{r}-0.81 \\
(0.72)\end{array}$ & $\begin{array}{r}-0.99 \\
(0.73)\end{array}$ & $\begin{array}{c}-0.77 \\
(0.75)\end{array}$ & $\begin{array}{r}-1.62^{*} \\
(0.75)\end{array}$ & $\begin{array}{r}-1.75^{*} \\
(0.77)\end{array}$ & $\begin{array}{r}-1.88^{*} \\
(0.77)\end{array}$ & $\begin{array}{r}-1.44^{*} \\
(0.74)\end{array}$ & $\begin{array}{r}-1.87^{*} \\
(0.82)\end{array}$ \\
\hline Year 1993 & $\begin{array}{r}-1.28 \dagger \\
(0.70)\end{array}$ & $\begin{array}{r}-1.48^{*} \\
(0.73)\end{array}$ & $\begin{array}{r}-1.28 \dagger \\
(0.72)\end{array}$ & $\begin{array}{c}-1.95^{* *} \\
(0.75)\end{array}$ & $\begin{array}{c}-2.60^{* *} \\
(0.79)\end{array}$ & $\begin{array}{c}-2.60^{* *} \\
(0.81)\end{array}$ & $\begin{array}{c}-2.03^{* *} \\
(0.77)\end{array}$ & $\begin{array}{c}-2.86^{* *} \\
(0.88)\end{array}$ \\
\hline Year 1994 & $\begin{array}{r}-1.31 \dagger \\
(0.72)\end{array}$ & $\begin{array}{r}-1.57^{*} \\
(0.76)\end{array}$ & $\begin{array}{r}-1.28 \dagger \\
(0.76)\end{array}$ & $\begin{array}{c}-2.08^{* *} \\
(0.77)\end{array}$ & $\begin{array}{c}-3.46^{* * *} \\
(0.79)\end{array}$ & $\begin{array}{c}-3.56^{* * *} \\
(0.85)\end{array}$ & $\begin{array}{c}-2.81^{* *} \\
(0.84)\end{array}$ & $\begin{array}{c}-3.72^{* * *} \\
(0.87)\end{array}$ \\
\hline Year 1995 & $\begin{array}{r}-0.16 \\
(0.72)\end{array}$ & $\begin{array}{r}-0.52 \\
(0.79)\end{array}$ & $\begin{array}{r}-0.19 \\
(0.73)\end{array}$ & $\begin{array}{r}-1.06 \\
(0.77)\end{array}$ & $\begin{array}{c}-3.93^{* * *} \\
(0.81)\end{array}$ & $\begin{array}{c}-4.32^{* * *} \\
(0.89)\end{array}$ & $\begin{array}{c}-3.82^{* * *} \\
(0.93)\end{array}$ & $\begin{array}{c}-4.38^{* * *} \\
(0.93)\end{array}$ \\
\hline Constant & $\begin{array}{r}-4.71^{*} \\
(1.96)\end{array}$ & $\begin{array}{l}-4.54^{* *} \\
(21.71)\end{array}$ & $\begin{array}{c}-3.04 \\
(2.23)\end{array}$ & $\begin{array}{c}-8.06^{* * *} \\
(2.14)\end{array}$ & $\begin{array}{c}-6.26^{* *} \\
(2.18)\end{array}$ & $\begin{array}{c}-5.92^{* * *} \\
(2.17)\end{array}$ & $\begin{array}{c}2.82 \\
(2.49)\end{array}$ & $\begin{array}{c}-10.99^{* * *} \\
(2.65)\end{array}$ \\
\hline $\begin{array}{l}\chi^{2} \\
\text { d.f. } \\
n\end{array}$ & $\begin{array}{c}24.37 \\
17 \\
1329\end{array}$ & $\begin{array}{c}46.05^{* * *} \\
18 \\
1329\end{array}$ & $\begin{array}{c}25.86 \\
19 \\
1329\end{array}$ & $\begin{array}{c}52.07^{* * *} \\
19 \\
1329\end{array}$ & $\begin{array}{c}37.59^{* * *} \\
17 \\
1329\end{array}$ & $\begin{array}{c}55.73^{* * *} \\
18 \\
1329\end{array}$ & $\begin{array}{c}59.74^{* * *} \\
19 \\
1329\end{array}$ & $\begin{array}{c}49.16^{* * *} \\
19 \\
1329\end{array}$ \\
\hline
\end{tabular}

${ }^{a}$ Unstandardized coefficients. One-way tests for hypothesized effects, two-way tests otherwise.

$\dagger p<0.10 ;{ }^{*} p<0.05 ;{ }^{* *} p<0.01 ;{ }^{* * *} p<0.001$ 
is also more strongly associated with both high related and high unrelated diversification $\left(\chi^{2}(1)=\right.$ $10.69, p<0.01$ and $\left.\chi^{2}(1)=14.51, p<0.001\right)$, thus supporting Hypothesis 5. Interestingly, having finance non-CEO directors actually reduces the likelihood a firm is highly diversified, which provides further support for the agency argument that CEOs and other corporate elites may have markedly different revealed preferences for diversification. The differences across Models 2-4 and 6-8 suggest the value of distinguishing between individuals occupying the CEO position and all the other corporate elites to understand more fully the association between functional background and diversification.

These results illustrate the subtleties in the empirical relationships between corporate elites' functional background experiences and diversification, and also suggest that the use of aggregate units of analysis may be problematic. Specifically, the results show that aggregate effects, which appear to indicate no significant relationships, in fact may mask significant disaggregate effects. The positive and significant finance CEO effect would have remained undetected had we not parsed out the differences in governance position. The results thus illustrate the importance of considering both demography and governance position in analyses of corporate elites' effects on strategy. Stated differently, our study reveals the danger of mistakenly viewing all corporate elites as part of a like-minded team.

\section{Acquisitions}

Table 3 reports the results of random-effects tobit regression analyses of acquisition activity. Model 2 shows that, contrary to Hypothesis 2, having more finance corporate elites actually decreases a firm's propensity for acquisition activity. However, Models 3 and 4 show (similar to the diversification findings discussed above) that failing to consider differences in governance positions masks important differences in predicting acquisition activity. Specifically, Model 3 indicates that the surprisingly strong negative effect of finance corporate elites on acquisitions in Model 2 is based on a negative effect of finance non-executive directors, not finance executive directors. However, since the effect of finance executive directors is not significantly different $(F(1,1308)=2.90 ; p>0.05)$ from the effect of finance non-executive directors,
Hypothesis 4 cannot be supported: finance executive directors are not associated with more acquisition activity than finance non-executive directors.

Finally, Model 4 shows once again the empirical importance of our theoretical choice to completely disaggregate the units of analysis. It shows that the insignificant finance executive director effect in Model 3 in fact masks a significant finance CEO effect. Moreover, the finance CEO effect is significantly larger than the effect of finance non-CEO directors $(F(1,1308)=6.56$; $p<0.05)$. This supports Hypothesis 6, which argued that finance CEOs compared to finance non-CEO directors are associated with more acquisition activity. Thus, the overall negative finance director effect in Model 2 is more appropriately expressed in terms of a positive finance CEO effect and a negative finance non-CEO director effect. This conclusion is again, as noted above, validated by the overall improvements in the significance of the acquisition models. Separate analyses also showed that the non-CEO executive directors align more closely with the non-executive directors, even when controlling for power interactions. These results thus confirm the diversification results, suggesting that it is critically important to consider the importance of governance positions when analyzing the effects of demographic characteristics on corporate strategy.

To assess the substantive significance of using disaggregate units of analysis, we also calculated the dollar equivalents of the acquisition models' tobit coefficients and their two constitutive parts. The tobit coefficients indicate the marginal propensity or capacity of a firm to engage in acquisition activities and can be transformed into dollar values to provide more intuitive and substantive interpretation of the effects (Breen, 1996). Expressed in dollar values, replacing a non-finance CEO with a finance CEO results in roughly $\$ 103$ million more spent on acquisitions per year (these values are calculated at the mean level of the independent variables (Breen, 1996)). Following McDonald and Moffitt (1980), these effects can be decomposed into two subeffects which show that most of the finance CEO effect derives from increasing the probability of doing acquisitions ( $\$ 65$ million or 63 percent), whereas a smaller part derives from increasing the size of the acquisitions ( $\$ 38$ million or 37 percent). The marginal effect of finance nonCEO directors is quite different. It reduces the average size of acquisitions by roughly $\$ 53$ million 
Table 3. Random-effects tobit regression: acquisitions ${ }^{\mathrm{a}}$

\begin{tabular}{|c|c|c|c|c|}
\hline & (1) & $(2)$ & (3) & (4) \\
\hline Finance corporate elites (\#) & & $\begin{array}{r}-91.59^{*} \\
(42.22)\end{array}$ & & \\
\hline Finance executive elites (\#) & & & $\begin{array}{c}-26.76 \\
(56.51)\end{array}$ & \\
\hline Finance non-executive elites (\#) & & & $\begin{array}{c}-137.65^{* *} \\
(50.57)\end{array}$ & \\
\hline Finance CEO (\#) & & & & $\begin{array}{c}199.98^{*} \\
(120.79)\end{array}$ \\
\hline Finance non-CEO elites (\#) & & & & $\begin{array}{c}-128.13^{* *} \\
(44.77)\end{array}$ \\
\hline Total number of corporate elites & $\begin{array}{r}-21.00 \\
(21.79)\end{array}$ & $\begin{array}{c}8.39 \\
(25.54)\end{array}$ & $\begin{array}{c}6.67 \\
(25.57)\end{array}$ & $\begin{array}{c}21.00 \\
(26.00)\end{array}$ \\
\hline CEO relative board tenure & $\begin{array}{c}-52.07 \\
(44.22)\end{array}$ & $\begin{array}{r}-50.59 \\
(43.93)\end{array}$ & $\begin{array}{c}-57.87 \\
(44.40)\end{array}$ & $\begin{array}{c}-51.58 \\
(44.11)\end{array}$ \\
\hline CEO duality & $\begin{array}{c}210.19 \\
(156.20)\end{array}$ & $\begin{array}{c}217.23 \\
(156.26)\end{array}$ & $\begin{array}{c}242.42 \\
(157.30)\end{array}$ & $\begin{array}{c}186.04 \\
(156.44)\end{array}$ \\
\hline Assets (ln) & $\begin{array}{l}437.26^{* * *} \\
(53.31)\end{array}$ & $\begin{array}{l}429.10^{* * *} \\
(53.20)\end{array}$ & $\begin{array}{l}424.20^{* * *} \\
(53.26)\end{array}$ & $\begin{array}{l}434.16^{* * *} \\
(53.07)\end{array}$ \\
\hline Debt/market $(\ln )$ & $\begin{array}{c}-54.44 \\
(58.78)\end{array}$ & $\begin{array}{c}-39.34 \\
(59.17)\end{array}$ & $\begin{array}{c}-39.59 \\
(59.23)\end{array}$ & $\begin{array}{c}-44.17 \\
(59.14)\end{array}$ \\
\hline Current ratio & $\begin{array}{l}116.71 \\
(91.99)\end{array}$ & $\begin{array}{l}103.46 \\
(92.06)\end{array}$ & $\begin{array}{l}109.35 \\
(92.37)\end{array}$ & $\begin{array}{c}99.11 \\
(92.16)\end{array}$ \\
\hline Return on assets (ROA) & $\begin{array}{r}24.45^{*} \\
(10.75)\end{array}$ & $\begin{array}{r}25.30^{*} \\
(10.77)\end{array}$ & $\begin{array}{c}24.99^{*} \\
(10.83)\end{array}$ & $\begin{array}{r}25.16^{*} \\
(10.86)\end{array}$ \\
\hline Diversification level $(t)$ & $\begin{array}{r}-670.78^{*} \\
(282.81)\end{array}$ & $\begin{array}{r}-624.42^{*} \\
(283.52)\end{array}$ & $\begin{array}{r}-600.31^{*} \\
(284.44)\end{array}$ & $\begin{array}{r}-675.03^{*} \\
(284.05)\end{array}$ \\
\hline Diversification level $^{2}(t)$ & $\begin{array}{r}368.43^{*} \\
(162.81)\end{array}$ & $\begin{array}{c}347.75^{*} \\
(162.98)\end{array}$ & $\begin{array}{r}342.62^{*} \\
(163.39)\end{array}$ & $\begin{array}{r}363.16^{*} \\
(162.92)\end{array}$ \\
\hline Year 1986 & $\begin{array}{c}375.97 \\
(242.79)\end{array}$ & $\begin{array}{c}388.87 \\
(242.40)\end{array}$ & $\begin{array}{c}393.11 \\
(243.13)\end{array}$ & $\begin{array}{c}375.17 \\
(242.17)\end{array}$ \\
\hline Year 1987 & $\begin{array}{l}121.54 \\
(253.51)\end{array}$ & $\begin{array}{l}124.94 \\
(253.36)\end{array}$ & $\begin{array}{l}130.06 \\
(254.05)\end{array}$ & $\begin{array}{c}116.84 \\
(252.83)\end{array}$ \\
\hline Year 1988 & $\begin{array}{l}210.09 \\
(248.77)\end{array}$ & $\begin{array}{l}198.79 \\
(248.62)\end{array}$ & $\begin{array}{c}204.07 \\
(249.23)\end{array}$ & $\begin{array}{l}193.08 \\
(248.09)\end{array}$ \\
\hline Year 1989 & $\begin{array}{l}503.14^{*} \\
(243.59)\end{array}$ & $\begin{array}{l}501.12^{*} \\
(243.26)\end{array}$ & $\begin{array}{l}510.31^{*} \\
(244.02)\end{array}$ & $\begin{array}{c}498.44^{*} \\
(242.55)\end{array}$ \\
\hline Year 1990 & $\begin{array}{c}30.95 \\
(268.56)\end{array}$ & $\begin{array}{c}25.27 \\
(268.62)\end{array}$ & $\begin{array}{c}28.14 \\
(269.66)\end{array}$ & $\begin{array}{c}16.71 \\
(268.63)\end{array}$ \\
\hline Year 1991 & $\begin{array}{c}-130.35 \\
(273.56)\end{array}$ & $\begin{array}{r}-136.56 \\
(273.46)\end{array}$ & $\begin{array}{c}-123.82 \\
(274.46)\end{array}$ & $\begin{array}{l}-150.65 \\
(273.47)\end{array}$ \\
\hline Year 1992 & $\begin{array}{c}88.09 \\
(259.30)\end{array}$ & $\begin{array}{c}86.81 \\
(258.82)\end{array}$ & $\begin{array}{c}99.17 \\
(259.86)\end{array}$ & $\begin{array}{c}53.93 \\
(259.11)\end{array}$ \\
\hline Year 1993 & $\begin{array}{l}192.34 \\
(262.86)\end{array}$ & $\begin{array}{l}179.25 \\
(262.75)\end{array}$ & $\begin{array}{l}196.38 \\
(263.83)\end{array}$ & $\begin{array}{l}153.80 \\
(262.63)\end{array}$ \\
\hline Year 1994 & $\begin{array}{c}415.85 \\
(258.23)\end{array}$ & $\begin{array}{c}403.59 \\
(257.92)\end{array}$ & $\begin{array}{c}414.85 \\
(258.82)\end{array}$ & $\begin{array}{c}381.26 \\
(257.54)\end{array}$ \\
\hline Year 1995 & $\begin{array}{c}425.98 \\
(257.40)\end{array}$ & $\begin{array}{c}418.05 \\
(257.05)\end{array}$ & $\begin{array}{c}436.56 \\
(258.13)\end{array}$ & $\begin{array}{c}395.27 \\
(256.64)\end{array}$ \\
\hline Constant & $\begin{array}{c}-4968.19^{* * *} \\
(564.84)\end{array}$ & $\begin{aligned}- & 4914.82^{* * * *} \\
& (564.76)\end{aligned}$ & $\begin{array}{c}-4922.84^{* * *} \\
\quad(566.28)\end{array}$ & $\begin{array}{c}-4984.92^{* * *} \\
\quad(564.68)\end{array}$ \\
\hline $\begin{array}{l}\chi^{2} \\
\text { d.f. } \\
n\end{array}$ & $\begin{array}{c}115.62^{* * *} \\
19 \\
1329\end{array}$ & $\begin{array}{c}120.38^{* * *} \\
20 \\
1329\end{array}$ & $\begin{array}{c}123.30^{* * *} \\
21 \\
1329\end{array}$ & $\begin{array}{c}126.94^{* * *} \\
21 \\
1329\end{array}$ \\
\hline
\end{tabular}

${ }^{\mathrm{a}}$ Unstandardized coefficients. One-way tests for hypothesized effects, two-way tests otherwise.

$\dagger p<0.10$; $^{*} p<0.05 ;{ }^{* *} p<0.01 ;{ }^{* * *} p<0.001$ 
a year split between $\$ 13$ million less for firms already acquiring and $\$ 40$ million less from lowering the probability of engaging in the activity. The problems of aggregate units of analysis are clearly illustrated by comparing the detailed information obtained from the disaggregated finance CEO and finance non-CEO director variables on the one hand and the aggregate finance corporate director variable on the other hand. Had we stopped with the aggregate-level analysis, we would simply have concluded that the marginal effect of finance corporate directors is to reduce acquisitions by roughly $\$ 40$ million a year.

\section{Supplemental analyses}

Our prediction regarding an expected positive relationship between finance CEOs and highly diversified firms was based on our theorizing about finance CEOs having relatively stronger preferences for diversification (relative to non-finance CEOs). To further distinguish between finance CEOs' preferences for high levels of diversification vs. their particular expertise to create shareholder value through high levels of diversification, we collected additional data on firm performance and estimated a new set of regression models (see Appendix). If finance CEOs were using their expertise to create shareholder value through diversification, one would expect that highly diversified corporations with finance CEOs performed better than other highly diversified corporations. We defined performance in terms of relative changes in total shareholder value ([market capitalization ${ }_{t}+$ dividends $_{t}-$ market capitalization $\left._{t-1}\right] /$ market capitalization $_{t-1}$ ) and used the multiplicative interaction approach (Gupta and Govindarajan, 1993) to test whether there was a positive interaction effect on performance of having a finance CEO and being highly diversified. ${ }^{7}$

As the Appendix shows, the interaction effects are insignificant, indicating that highly diversified corporations with finance CEOs performed no better than other highly diversified firms. This suggests that the positive relationship that we hypothesized and found between finance CEOs and high diversification is not attributable to a finance CEO's unique expertise in creating shareholder

\footnotetext{
${ }^{7}$ We also tested used alternative performance indicators such as return on assets and price/earnings ratio and found similar results.

value through high levels of corporate diversification. In other words, we are now able to show that finance CEOs engage in significantly higher diversification, as hypothesized, and that this diversification is not creating shareholder value. ${ }^{8}$

\section{IMPLICATIONS AND CONCLUSIONS}

This study has sought to develop and test a theoretical framework that (1) combines insights from both the agency and the upper-echelons perspectives, and (2) highlights the importance of considering how both demography and position affect the relationship between corporate elites and corporate strategy. We argued-and found empirically - that focusing on only one aspect at the expense of the other may lead to an unfortunately narrow choice of units of analysis that can oversimplify or even mask the true relationship between corporate elites and the scope of the firm.

For example, there first appeared to be no support (or contradictory support) for the demographically based notion that corporate elites' functional background experiences affect diversification and acquisition activities. However, by taking governance position into account and disaggregating elites into seemingly more relevant governance positions, we demonstrated that the insignificant or contradictory effects of corporate elite demography mask significantly different subgroup effects. In the case of both unrelated diversification and acquisitions, the aggregate-level effects masked a positive finance CEO effect and a negative finance non-CEO effect. In other words, by pushing the agency theory argument that differences in governance positions imply differences in strategy preferences to its logical limit, we provided clearer insights into the role of elites' demography on corporate strategy. Given the increased popularity of aggregate units of analysis, such as the top management team or the board of directors, documented by Finkelstein and Hambrick (1996), the results of the present study suggest that caution should be exercised when interpreting research using these aggregate units of analysis.

\footnotetext{
${ }^{8}$ Of course, this does not imply that finance CEOs typically make worse decisions than non-finance CEOs when engaging in high levels of diversification, or that they never increase shareholder value. Rather, the absence of shareholder value creation due to high diversification by finance CEOs reflects the central tendencies found in our large sample of firms.
} 
Some scholars argue that aggregate executive units of analysis, such as the top management team, are superior to the CEO unit of analysis because they explain more variance than the CEO unit of analysis (Hage and Dewar, 1973; Bantel and Jackson, 1989; Finkelstein, 1992). While aggregate units of analysis that include the CEO may explain more variance than the CEO unit alone, our study makes a different point. We do not suggest excluding the CEO, non-CEO executives, or non-executives from analyses of corporate elites and corporate strategy. Instead, we suggest that it is critically important to aggregate or disaggregate along the appropriate governance positions. In fact, our study suggests the value of including the CEO, non-CEO executives, and non-executive directors - but distinguishing between them.

We would therefore advocate precisely the opposite approach: rather than focusing on the corporate elites as an aggregate whole, one should distinguish between all the different subgroups of corporate elites that occupy similar governance position. Where this is not feasible, an alternative strategy would be to return to the simple CEO unit of analysis. While this strategy has the disadvantage of not considering the other corporate elites and making it impossible to address grouplevel phenomena such as group heterogeneity (e.g., Wiersema and Bantel, 1992), it is at least relatively unambiguous (our study showed that the completely disaggregated model, which isolated the CEO effects, generally had greater predictive significance).

While we have focused specifically on the agency context to address the interplay between governance position and demography, future research could also examine whether other contextual factors might have similar influence on corporate elites' demographic preferences. Indeed, some scholars have begun focusing on relationship between different organizational and environmental contexts and corporate elites structure and composition (e.g., Keck and Tushman, 1993; Keck, 1997). However, our findings still highlight the need for corporate elite-based research to consider how the relationships under study may differ according to the alternative governance positions corporate elites occupy.

Another contribution that we hope emerges from our joint demography/agency perspective is the focus on when one is likely to observe phenomena such as very high levels of diversification.
While agency researchers have alleged such behaviors in broad terms, they have not isolated where and why certain corporate elites are more likely to exhibit these specific behaviors. We believe our study is distinctive in actually assessing the extent to which demographically based preferences (such as those stemming from a particular functional background) lead to extreme behaviors (rather than simply above-average levels of behavior) among individual corporate elites. We hope that our theoretical recognition of the aggregation problem in TMT research, along with our attempt to very carefully analyze this issue empirically, will represent an important contribution in redirecting research in this area.

Finally, we would also like to note that, irrespective of the disaggregation question, the study's findings highlight that corporate elites do in fact influence corporate strategies above and beyond economic factors such as prior performance, resource scarcity, and firm size. In this way, we see the study as contributing to the larger body of corporate strategy research on diversification and acquisitions. Given that numerous prior studies have used either the agency or the upper-echelons perspectives to study these phenomena, this empirical context was very well suited for highlighting how our attempt at a more nuanced, synthetic approach could add to that line of inquiry. In this way, we also hope our study is seen as providing a behavioral complement to the more traditional economic perspectives on diversification and acquisitions.

\section{ACKNOWLEDGEMENTS}

We would like to thank J. Richard Harrison, Matt Kraatz, Willie Ocasio, Jim Westphal, and seminar participants at Northwestern University for their helpful comments. We thank Rick Johnson and Bob Hoskisson for allowing us to access some of their data, and Noriko Shiomi for providing valuable assistance in data collection. Both authors contributed equally.

\section{REFERENCES}

American Law Institute. 1984. Principles of Corporate Governance. Draft 2. 
Amihud Y, Lev B. 1981. Risk reduction as a managerial motive for conglomerate mergers. Bell Journal of Economics 12: 605-616.

Bantel KA, Jackson SE. 1989. Top management and innovations in banking: does the composition of the top team make a difference? Strategic Management Journal, Summer Special Issue 10: 107-124.

Beatty RP, Zajac EJ. 1994. Managerial incentives, monitoring, and risk bearing: a study of executive compensation, ownership, and board structure in initial public offerings. Administrative Science Quarterly 39: 313-335.

Beyer JM, Chattopadhyay P, George E, Glick WH, ogilvie dt, Pugliese D. 1997. The selective perception of managers revisited. Academy of Management Journal 40: 716-737.

Breen R. 1996. Regression Models: Censored, Sample Selected, or Truncated Data. Sage: Thousand Oaks, CA.

Business Roundtable. 1990. Corporate Governance and American Competitiveness.

Cannella AA Jr, Monroe MJ. 1997. Contrasting perspectives on strategic leaders: toward a more realistic view of top managers. Journal of Management 23: 213-237.

Chatterjee S, Wernerfelt B. 1991. The link between resources and type of diversification: theory and evidence. Strategic Management Journal 12(1): 33-48.

Chattopadhyay P, Glick WH, Miller CC, Huber GP. 1999. Determinants of executive beliefs: comparing functional conditioning and social influence. Strategic Management Journal 20(8): 763-789.

Chintagunta PK, Jain DC, Vilcassim NJ. 1991. Investigating heterogeneity in brand preferences in logit models for panel data. Journal of Marketing Research 28: 417-428.

D'Aveni RA, Kesner IF. 1993. Top managerial prestige, power and tender offer response: a study of elite social networks and target firm cooperation during takeovers. Organization Science 4: 123-151.

Dalton DR, Daily CM, Ellstrand AE, Johnson JL. 1998. Meta-analytic reviews of board composition, leadership structure, and financial performance. Strategic Management Journal 19(3): 269-290.

Dearborn DC, Simon HA. 1958. Selective perception: a note on the departmental identifications of executives. Sociometry 21: 140-144.

Demb A, Neubauer FF. 1992. The Corporate Board. Oxford University Press: Oxford.

Fama EF. 1980. Agency problems and the theory of the firm. Journal of Political Economy 88: 288-307.

Fama EF, Jensen MC. 1983. Separation of ownership and control. Journal of Law and Economics 26: 301-325.

Finkelstein S. 1992. Power in top management teams: dimensions, measurement, and validation. Academy of Management Journal 35: 505-538.

Finkelstein S, Hambrick DC. 1990. Top-managementteam tenure and organizational outcomes: the moderating roles of managerial discretion. Administrative Science Quarterly 35: 484-503.
Finkelstein S, Hambrick DC. 1996. Strategic Leadership: Top Executives and Their Effects on Organizations. West: St Paul, MN.

Fligstein N. 1987. The intraorganizational power struggle: rise of finance personnel to top leadership in large corporations, 1919-1979. American Sociological Review 52: 44-58.

Fligstein N. 1990. The Transformation of Corporate Control. Harvard University Press: Cambridge, MA.

Gomez-Mejia LR, Wiseman RM. 1997. Reframing executive compensation: an assessment and outlook. Journal of Management 23: 291-374.

Goodstein J, Boeker W. 1991. Turbulence at the top: a new perspective on governance structure changes and strategic change. Academy of Management Journal 34: 306-330.

Greene WH. 1997. Econometric Analysis. Prentice-Hall: Englewood Cliffs, NJ.

Gupta AK, Govindarajan V. 1993. Methodological issues in testing contingency theories: an assessment of alternative approaches. In Creative and Innovative Approaches to the Science of Management, Ijiri Y (ed). Quorum: Westport, CT; 453-471.

Hage J, Dewar R. 1973. Elite values versus organizational structure in predicting innovation. Administrative Science Quarterly 18: 279-290.

Haleblian J, Finkelstein S. 1993. Top management team size, CEO dominance, and firm performance: the moderating roles of environmental turbulence and discretion. Academy of Management Journal 36: 844-863.

Hambrick DC. 1994. Top management group: a conceptual integration and reconsideration of the 'team' label. In Research in Organizational Behavior, Staw BM, Cummings LL (eds). JAI Press: Greenwich, CT; 171-213.

Hambrick DC, Mason PA. 1984. Upper echelons: the organization as a reflection of its top managers. Academy of Management Review 9: 193-206.

Haunschild PR, Henderson AD, Davis-Blake A. 1999. CEO demographics and acquisitions: network effects of educational and functional background. In Corporate Social Capital and Liability, Leenders RTAJ, Gabbay SM (eds). Kluwer: Boston, MA; 266-283.

Hayes RH, Abernathy WJ. 1980. Managing our way to economic decline. Harvard Business Review 58(4): 67-77.

Hayward MLA, Hambrick DC. 1997. Explaining the premiums paid for large acquisitions: evidence of CEO hubris. Administrative Science Quarterly 42: 103-127.

Heckman JJ. 1981. The incidental parameters problem and the problem of initial conditions in estimating a discrete time-discrete data stochastic process. In Structural Analysis of Discrete Data with Econometric Applications, Manski C, McFadden D (eds). MIT Press: Cambridge, MA; 179-195.

Hoskisson RE, Hitt MA. 1994. Downscoping: How to Tame the Diversified Firm. Oxford University Press: New York.

Hoskisson RE, Hitt MA, Johnson RA, Moesel DD. 1993. Construct validity of an objective (entropy) categorical 
measure of diversification strategy. Strategic Management Journal 14(3): 215-235.

Hoskisson RE, Johnson RA, Moesel DD. 1994. Corporate divestiture intensity in restructuring firms: effects of governance, strategy, and performance. Academy of Management Journal 37: 1207-1251.

Jackson SE. 1992. Consequences of group composition for the interpersonal dynamics of strategic issue processing. In Advances in Strategic Management, Vol. 8, Shrivastava P, Huff AS, Dutton JE (eds). JAI Press: Greenwich, CT; 345-382.

Jensen MC. 1986. Agency costs of free cash flow, corporate finance, and takeovers. American Economic Review 76: 323-329.

Jensen MC, Meckling WH. 1976. Theory of the firm: managerial behavior, agency costs, and ownership structure. Journal of Financial Economics 3: $305-360$.

Judge GG, Griffiths WE, Hill RC, Lee T-C. 1985. The Theory and Practice of Econometrics. Wiley: New York.

Keck SL. 1997. Top management team structure: differential effects by environmental context. Organization Science 8: 143-156.

Keck SL, Tushman ML. 1993. Environmental and organizational context and executive team structure. Academy of Management Journal 36: 1314-1344.

Lane PJ, Cannella AA Jr, Lubatkin MH. 1998. Agency problems as antecedents to unrelated diversification: Amihud and Lev reconsidered. Strategic Management Journal 19(6): 555-578.

Lorsch JW, MacIver E. 1989. Pawns or Potentates: The Reality of America's Corporate Boards. Harvard Business School Press: Boston, MA.

Mallette P, Fowler KL. 1992. Effects of board composition and stock ownership on the adoption of poison pills. Academy of Management Journal 35: 1010-1035.

Markides CC. 1995. Diversification, Refocusing, and Economic Performance. MIT Press: Cambridge, MA.

McDonald JF, Moffitt RA. 1980. The uses of tobit analysis. Review of Economics and Statistics 62: 318-321.

McNulty T, Pettigrew AM. 1996. The contribution, power and influence of part-time board members. Corporate Governance 4: 160-179.

Michel JG, Hambrick DC. 1992. Diversification posture and top management team characteristics. Academy of Management Journal 35: 9-35.

Montgomery CA. 1982. The measurement of firm diversification: some new empirical evidence. Academy of Management Journal 28: 299-307.

Ocasio W. 1994. Political dynamics and the circulation of power: CEO succession in U.S. industrial corporations, 1960-1990. Administrative Science Quarterly 39: 285-312.

Palepu K. 1985. Diversification strategy, profit performance and the entropy measure. Strategic Management Journal 6(3): 239-255.

Palmer D, Barber BM. 2001. Challengers, elites, and owning families: a social class theory of corporate acquisitions in the 1960s. Administrative Science Quarterly 46: 87-120.

Petersen T, Koput KW. 1991. Density dependence in organizational mortality: legitimacy or unobserved heterogeneity? American Sociological Review 56: 399-409.

Salter MS, Weinhold WA. 1978. Diversification via acquisition: creating value. Harvard Business Review 56(4): 166-176.

Sayrs LW. 1989. Pooled Time Series Analysis. Sage: Newbury Park, CA.

Song JH. 1982. Diversification strategies and the experience of top executives of large firms. Strategic Management Journal 3(4): 377-380.

Tobin J. 1958. Estimation of relationships for limited dependent variables. Econometrica 26: 24-36.

Tosi HL, Gomez-Mejia LR. 1989. The decoupling of CEO pay and performance: an agency theory perspective. Administrative Science Quarterly 34: 169-189.

Waller MJ, Huber GP, Glick WH. 1995. Functional background as a determinant of executive perception. Academy of Management Journal 38: 943-974.

Walsh JP. 1988. Selectivity and selective perception: an investigation of managers' belief structures and information processing. Academy of Management Journal 31: 873-896.

Walsh JP, Seward JK. 1990. On the efficiency of internal and external corporate control mechanisms. Academy of Management Review 15: 421-458.

Westphal JD. 1998. Board games: how CEOs adapt to increases in structural board independence from management. Administrative Science Quarterly 43: 511-537.

Westphal JD, Zajac EJ. 1997. Defections from the inner circle: social exchange, reciprocity, and the diffusion of board independence in U.S. corporations. Administrative Science Quarterly 42: 161-183.

Wiersema MF, Bantel KA. 1992. Top management team demography and corporate strategic change. Academy of Management Journal 35: 91-121.

Zajac EJ, Westphal JD. 1996. Director reputation, CEO/board power, and the dynamics of board interlocks. Administrative Science Quarterly 41: 507-529. 
APPENDIX: FIXED-EFFECTS OLS REGRESSION: TOTAL SHAREHOLDER RETURN $^{\mathrm{a}}$

\begin{tabular}{|c|c|c|}
\hline & $(1)$ & $(2)$ \\
\hline High related diversification $(0-1)$ & $\begin{array}{c}0.04 \\
(0.06)\end{array}$ & \\
\hline High unrelated diversification $(0-1)$ & & $\begin{array}{c}0.02 \\
(0.06)\end{array}$ \\
\hline Finance CEO (\#) & $\begin{array}{r}-0.04 \\
(0.04)\end{array}$ & $\begin{array}{r}-0.05 \\
(0.07)\end{array}$ \\
\hline Finance CEO $*$ High related diversification & $\begin{array}{c}0.01 \\
(0.02)\end{array}$ & \\
\hline Finance CEO $*$ High unrelated diversification & & $\begin{array}{c}0.06 \\
(0.07)\end{array}$ \\
\hline Acquisition $(0-1)$ & $\begin{array}{c}-0.01 \\
(0.02)\end{array}$ & $\begin{array}{c}-0.01 \\
(0.02)\end{array}$ \\
\hline Divestiture $(0-1)$ & $\begin{array}{r}-0.05^{*} \\
(0.02)\end{array}$ & $\begin{array}{r}-0.05^{*} \\
(0.02)\end{array}$ \\
\hline Finance non-CEO elites (\#) & $\begin{array}{r}-0.03^{*} \\
(0.01)\end{array}$ & $\begin{array}{c}-0.03 \dagger \\
(0.01)\end{array}$ \\
\hline Total number of corporate elites & $\begin{array}{c}0.02 \dagger \\
(0.01)\end{array}$ & $\begin{array}{c}0.02 \dagger \\
(0.01)\end{array}$ \\
\hline CEO relative board tenure & $\begin{array}{c}-0.02 \dagger \\
(0.01)\end{array}$ & $\begin{array}{c}-0.01 \dagger \\
(0.03)\end{array}$ \\
\hline CEO duality & $\begin{array}{c}-0.01 \\
(0.03)\end{array}$ & $\begin{array}{c}-0.01 \\
(0.03)\end{array}$ \\
\hline Assets (ln) & $\begin{array}{c}-0.36^{* * *} \\
(0.05)\end{array}$ & $\begin{array}{c}-0.36^{* * *} \\
(0.05)\end{array}$ \\
\hline Debt/market (ln) & $\begin{array}{l}0.16^{* * *} \\
(0.03)\end{array}$ & $\begin{array}{l}0.16^{* * *} \\
(0.03)\end{array}$ \\
\hline Current ratio & $\begin{array}{c}-0.06 \dagger \\
(0.03)\end{array}$ & $\begin{array}{c}-0.06 \dagger \\
(0.03)\end{array}$ \\
\hline Return on assets (ROA) & $\begin{array}{c}-0.00 \\
(0.00)\end{array}$ & $\begin{array}{c}-0.00 \\
(0.00)\end{array}$ \\
\hline Constant & $\begin{array}{l}3.06^{* * *} \\
(0.38)\end{array}$ & $\begin{array}{l}3.07^{* * *} \\
(0.38)\end{array}$ \\
\hline $\begin{array}{l}R^{2} \\
F(22,1003)\end{array}$ & $\begin{array}{c}0.23 \\
13.42^{* * *}\end{array}$ & $\begin{array}{c}0.23 \\
13.44^{* * *}\end{array}$ \\
\hline$n$ & 1179 & 1179 \\
\hline
\end{tabular}

